\title{
Pendidikan Pancasila
}

Studi Kasus:

Analisis Atas Indonesia

"Penutupan Tiga Bangunan Gereja di Kota Jambi, Tanpa Adanya Surat Penyegelan" (Negara Kekuasaan, Pengurus, Kesatuan, Kekeluargaan, Federal, atau Negara Agama?)

\section{Dosen Pengampu:}

DR. AGUSTINUS W. DEWANTARA, S.S., M.HUM.

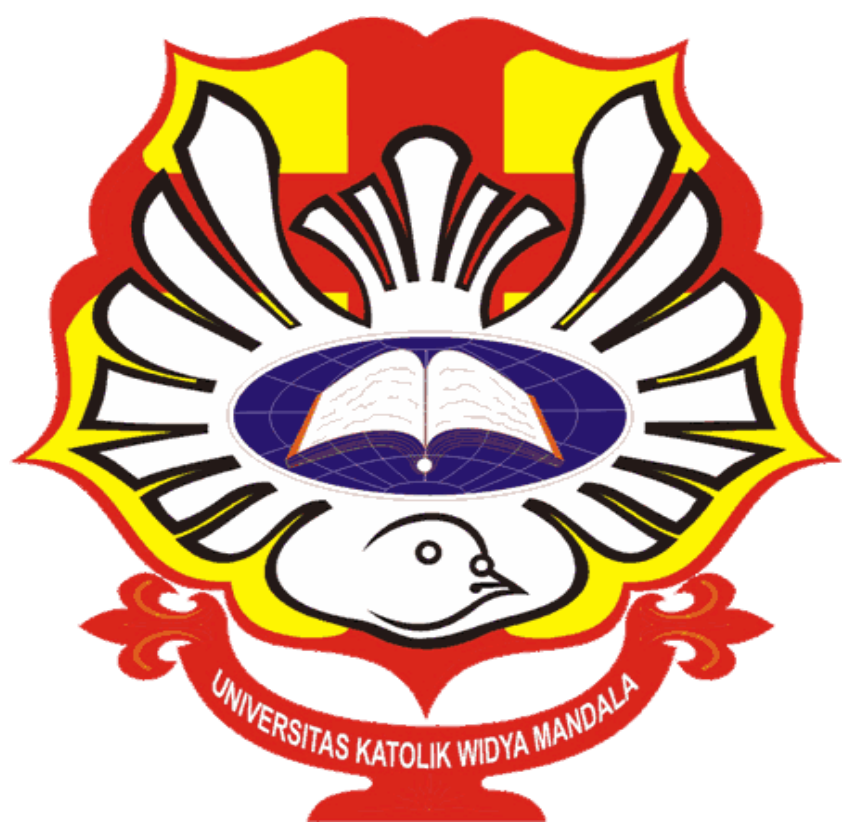

Oleh:

EMANUEL HARIDASTIAN

NIM: 12417002

PROGRAM STUDI PENDIDIKAN BAHASA DAN SASTRA INDONESIA

FAKULTAS KEGURUAN DAN ILMU PENDIDIKAN

UNIVERSITAS KATOLIK WIDYA MANDALA MADIUN

2019 


\begin{abstract}
Abstrak
Paper ini berjudul Analisis Atas Indonesia "Penutupan Tiga Bangunan Gereja di Kota Jambi, Tanpa Adanya Surat Penyegelan” (Negara Kekuasaan, Pengurus, Kesatuan, Kekeluargaan, Federal, atau Negara Agama?). Pembuatan paper menggunakan metode penganalisisan sebuah kasus yang terjadi dan ditinjau menggunakan teori-teori pembelajaran yang terdapat pada buku Diskursus Filsafat Pancasila. Data kasus yang di pakai dalam penulisan paper ini adalah berita kasus yang bersumber dari internet dengan alamat Sumber: https://www.bbc.com/indonesia/indonesia-45675216. Paper ini merupakan tugas akhir perkuliahan Pendidikan Pancasila semester IV tahun 2019, dan menjadi syarat mengikuti ujian akhir semester.
\end{abstract}

Hasil analisis yang didapatkan ialah sebagai berikut: Pada analisis kali ini saya akan menggunakan teori Negara dan Agama yang bersumber dari buku Diskusi Filsafat Pancasila Dewasa Ini, karangan DR. Agustinus W. Dewantara, S.S., M.HUM.

Indonesia adalah negara kesatuan yang di bentuk oleh tokoh-tokoh terdahulu bangsa Indonesia. Negara yang berlandaskan ideologi dengan dasar negara yang di sebut Pancasila, perundingan pembentukan negara yang dilakukan secara demokrasi dan mufakat pada akhirnya berhasil medirikan suatu negara yang diinginkan bersama yaitu Negara kesatuan Repiblik Indonesia (NKRI).

Negara agama, apakah itu? Negara agama artinya, konstitusi yang dibuat sebagai fondasi, negara mencantumkan agama sebagai salah satu fondasinya. Maksudnya, ditulis secara tegas, bahwa agama dari negara ialah demikian. Dari sudut pandang konstitusional seperti ini, Indonesia jelas bukan negara agama. Tetapi, Indonesia juga tidak memiliki elemen-elemen untuk disebut sebagai negara sekuler secara tegas. Negara sekuler artinya negara melepaskan diri dari hegemoni agama. Indonesia masih menyisakan banyak perkara pada soal-soal yang masih berkaitan dengan agama. Agama menjadi salah satu faktor penting untuk menjalankan kehidupan bersama.

Jika teori tersebut dikaitkan dengan kasus yang sedang terjadi di kota Jambi, mengenai penutupan gereja tanpa adanya surat penyegelan, maka saya berpendapat bahwa di kota tersebut masih mengalami yang namanya hidup berkelompok dengan golongan tertentu dan masih adanya kegiatan intoleran dengan golongan lainnya. 
Argumentasi lain, adalah kontradiksi menyisipkan kata-kata rumusan Piagan Jakarat ke Pembukaan UUD 1945, apalagi ke dalam rumusan Pancasila. Kontradiksinya terletak di sini. Yaitu, bahwa aneka seruan dan kosakata dari Pembukaan UUD 1945 dan konstitusi pada umumnya (apalagi kalau itu berkaitan dengan negara demokrasi) ialah kebebasan, hak, keadaan, dan seterusnya.

Indonesia didirikan untuk semua warga Indonesia. Dengan kata lain, jangan lagi mengedepankan agama jika sudah berbicara mengenai ke-indonesia-an. Semangat gotong royong bangsa ini sudah terpatri dalam sanubari manusia Indonesia sejak semula. Hebatnya hal tersebut dilalui dengan musyawarah-mufakat dalam mencapai persetujuan bagi kebaikan bangsa yang majemuk secara keseluruhan. Berikut ini merupakan isi selengkapnya mengenai paper yang saya tuliskan.

\section{Kata kunci}

Negara dan Agama, Penyegelan Gereja, Kebangsaan. 


\section{"Penutupan Tiga Bangunan Gereja di Kota Jambi, Tanpa Adanya Surat Penyegelan"}

(Penyegelan Gereja Methodist Kanaan Jambi, GSJA, dan HKI tanpa disertai surat perintah Penyegelan).

Pemerintah kota Jambi menutup tiga gereja pada Kamis (29/9) karena tidak memiliki Izin Mendirikan Bangunan (IMB). Padahal, permohonan izin sudah diajukan bertahun-tahun. Tiga gereja yang disegel: GMI Kanaan Jambi, GSJA, dan HKI, semuanya berlokasi di Simpang Rimbo, Jambi, dan tanpa disertai surat segel dari pemerintah kota Jambi.

"Sejak Kamis (27/9) disegel sampai hari ini, Jumat (28/9), kami tidak pernah menerima surat penyegelan, tiba-tiba mereka datang menutup gereja," kata pendeta gereja HKI, Paradon Pasaribu. Selain karena tidak memiliki IMB, Pendeta Paradon mengatakan bahwa alasan penyegelan gereja itu adalah akibat menyalahi peraturan daerah lain terkait membuat keributan. Media nasional melaporkan bahwa penyegelan itu adalah solusi "sementara" yang ditawarkan Kesatuan Bangsa dan Politik (Kesbangpol) kota Jambi.

Kepala Kesatuan Bangsa dan Politik (Kesbangpol) Kota Jambi, Liphan Pasaribu, seperti dilaporkan di media nasional, mengatakan penyegelan adalah solusi "sementara". "Sementara ditutup dulu gerejanya. Disegel untuk dicarikan solusinya, pimpinan akan rapat mencari solusinya seperti di Aurduri dulu," kata Liphan Pasaribu, Kepala Kesbangpol kota Jambi.

Berdasarkan informasi yang diterima Pendeta Paradon, sekelompok warga dari Kelurahan Kenali Besar di kota Jambi telah menyurati walikota dan menyatakan keberatan akan keberadaan gerejanya.

\section{Tidak mendapatkan izin}

Sejak didirikan pada 2010 lalu, Gereja HKI telah mengajukan Izin Mendirikan Bangunan (IMB) namun hingga saat ini izin masih belum keluar.

"Sekitar kami ini mayoritas adalah umat Kristen, kami kumpulkan syarat yang tertuang dari SKB, tanda tangan masyarakat sekitar gereja, bahkan ada tanda tangan warga yang beragama di luar kristen." ungkap Pendeta Paradon. Namun, ditambahkannya, ketika semua syarat telah 
dipenuhi, justru banyak yang keberatan sehingga tak bisa mengajukan izin ke Kementerian Agama di kota Jambi.

Menurut Peraturan Bersama Menteri Agama dan Menteri Dalam Negeri tahun 2006, gereja harus mengumpulkan setidaknya $90 \mathrm{KTP}$ anggota gereja yang disahkan oleh pejabat setempat, persetujuan setidaknya 60 anggota masyarakat yang tinggal di lingkungan sekitar gereja yang dilegitimasi lurah atau kepala desa. Kemudian rekomendasi tertulis dari Kepala atau Kantor Kementerian Agama setempat, dan sepucuk surat berisi rekomendasi tertulis dari Forum Komunikasi Umat Beragama (FKUB) di tingkat Kabupaten atau Kota.

"Pemerintah bukan tak mau mengeluarkan izin tetapi salah satu syarat untuk mendirikan rumah ibadah yakni rekomendasi FKUB belum ada," kata Liphan seperti dikutip di media nasional. Ini bukanlah penyegelan tempat ibadah yang pertama di kota Jambi. Sebelumnya, Gereja HKBP Syalom Aur Duri disegel pada dan butuh 20 tahun untuk mengantongi Izin Mendirikan Bangunan (IMB).

Sumber: https://www.bbc.com/indonesia/indonesia-45675216 
Beranjak dari sebuah kasus yang terjadi di kota Jambi yang terdapat pada teks berita di atas, maka saya akan sedikit melakukan analisi atas Indonesia, dengan adanya kasus-kasus hakhak kemanusiaan yang masih sangat kurang mendapat perhatian dari pemerintahan yang masih menggunakan sistim mayoritas dan minoritas suatu bangsa. Pada analisis kali ini saya akan menggunakan teori Negara dan Agama yang bersumber dari buku Diskusi Filsafat Pancasila Dewasa Ini, karangan DR. Agustinus W. Dewantara, S.S., M.HUM.

\section{Negara dan Agama}

Negara agama, apakah itu? Negara agama artinya, konstitusi yang dibuat sebagai fondasi, negara mencantumkan agama sebagai salah satu fondasinya. Maksudnya, ditulis secara tegas, bahwa agama dari negara ialah demikian. Dari sudut pandang konstitusional seperti ini, Indonesia jelas bukan negara agama. Tetapi, Indonesia juga tidak memiliki elemen-elemen untuk disebut sebagai negara sekuler secara tegas. Negara sekuler artinya negara melepaskan diri dari hegemoni agama. Indonesia masih menyisakan banyak perkara pada soal-soal yang masih berkaitan dengan agama. Agama menjadi salah satu faktor penting untuk menjalankan kehidupan bersama.

Indonesia pernah hampir menjadi negara agama. Hal ini menunjuk pada sidang kompromis yang disebut dengan, "Jakarta Charter." Bagaimana menganalisis peristiwa sejarah ini? Dengan ringkas orang dapat berkata bahwa Indonesia tidak mungkin dicakup dalam pengedepanan salah satu agana yang menyisakan yang lain di belakang. Indonesia teramat plural dan multicultural untuk direduksi ke sana.

Melihat dari teori di atas mengenai agama dan negara, tentunya kita sebagai bangsa Indonesia harus mengetahui sejarah terbentuknya negara Indonesia ini. Dimana para pendiri negara kita ini, berusaha sekuat tenaga mengumpulkan ide-ide dan pemikiran-pemikiran yang luar biasa agar dapat menciptakan suatu negara yang demokratis dan multicultural. Karena negara kita dihuni oleh berbagai masyarakat dari berbagai suku, agama, ras, dan aliran-aliran kepercayaan tertentu. Maka dari itu para pendiri negara kita ini memikirkan suatu ide-ide untuk membentuk negara kita ini.

Jika teori tersebut dikaitkan dengan kasus yang sedang terjadi di kota Jambi, mengenai penutupan gereja tanpa adanya surat penyegelan, maka saya berpendapat bahwa di kota tersebut masih mengalami yang namanya hidup berkelompok dengan golongan tertentu dan masih adanya kegiatan intoleran dengan golongan lainnya.

Mengapa demikian? Jika kita perhatikan dengan seksama kasus yang sedang terjadi di kota Jambi beberapa bulan lalu, kita dapat melihat bagaimana sikap masyarakat dengan golongan 
tertentu yang tidak bisa menerima adanya kegiatan dari golongan lainnya salain itu pemerintahanannya juga bisa dikatakan masih intoleran dengan keberadaan masyarakat golongan lain di kota itu. Hal itu dapat kita lihat dalam berita yang mengatakan bahwa Golongan masyarakat Kristen di kota tersebut sudah mengajukan izin mendirikan bnngunan sejak kurang lebih 10 tahun, namun tanggapan pemerintah sangat mengecewakan sekali. Pemerinta memberikan respon yang sangat mengecewakan sekali. Bagaimana mungkin perizinan mendirikan bangunan itu sangat sulit untuk diurus, apalagi golongan kristiani ini sudah menyediakan semua syarat yang diminta, namun pemerintah malah sama sekali tidak memberikan jawaban apa-apa, atas permohonan izin yang mereka minta.

Argumentasi lain, adalah kontradiksi menyisipkan kata-kata rumusan Piagan Jakarat ke Pembukaan UUD 1945, apalagi ke dalam rumusan Pancasila. Kontradiksinya terletak di sini. Yaitu, bahwa aneka seruan dan kosakata dari Pembukaan UUD 1945 dan konstitusi pada umumnya (apalagi kalau itu berkaitan dengan negara demokrasi) ialah kebebasan, hak, keadaan, dan seterusnya.

Menarik kesimpulan dari argumentasi di atas, bahwa kita bisa melihat kasus yang terjadi di kota Jambi tersebut, dimana hak-hak manyarakat sangat susah di dapatkan lalu bagaimana bisa terciptanya suatu masyarakat yang demokrasi di kota tersebut jika mayoritas golongan tertentu saja tidak dapat menerima adanya golongan minoritas di kota itu.

Kemudian, bagaimana cara pandang masyarakat tersebut mengenai UUD 1945 yang selalu berkaitan dengan Dasar Negara kita yaitu Pancasila? Jika melihat kembali kasus-kasus yang sama dengan kasus yang sedang terjadi kota jambi, maka dapat di katakan bahwa sebagian besar masyarakat di kota-kota tertentu yang pernah terjadi kasus serupa dengan kota jambi tersebut, mereka masih kurang memahami atau bahkan tidak memahami mengenai maksud dari dasar negara kita ini. Lalu untuk apa ada hak-hak asasi jika, masih ada saja masyarakat yang sering melakukan kesalahan yang serupa? Saya merasa di kota itu masih sering terjadi perpecahan golongan-golongan tertentu, dan golongan siapa yang kuat maka itu yang akan berkuasa pada wilayah itu. Lalu bagaimana cara golongan minoritas bisa mendapatkan kebebasan dan hak mereka?

Salah satu perkara paling rumit di indonesia ialah, memahami hubungan agama dan negara. Dalam sejarah peradaban Indonesia, soal ini merupakan kunci untuk banyak masalah dan kepentingan. Ketika soal ini terpecahkan, terselesaikan pula aneka perdebatan mengenai pemerintahan dan tata hidup bersama yang lain. Salah satu pendiri negara yang membahasa secara mandala tema ini ialah Soekarno. 
Dalam kebangsaan, menurut Soekarno, memberikan motivasi dan cara berpikir yang mengedepankan bangsa secara keseluruhan. Dasar ini tidak menyempitkan kita pada kepentingan golongan sendiri. Di sini, yang dimaksudkan golongan ialah kelompok bangsawan, kaum buruh, atau juga kelompok beragama. Soekarno dan para pendiri yang lain sadar bahwa masyarakat Indonesia adalah masyarakat agama. Kenyataan ini dapat membawa kepada cara-cara pandang tertentu yang mengunggulkan kelompok agama sendiri di atas keutuhan bangsa.

Kita mendirikan negara Indonesia, yang kita semua harus mendukungnya. Semua buat semua! Bukan Kristen buat Indonesia, bukan Islam buat Indonesia, bukan Hadikoesoemo buat in donesia, bukan Van Eck buat Indonesia, buka Nitisemito yang kaya buat Indonesia, tetapi Indonesia buat Indonesia, semua buat semua!. Kalimat inilah yang diucapkan oleh pendiri negara kita yaitu Soekarno dimana Bung karno mencoba merangkum lima nilai Pancasila menjasi satu nilai Pancasila yang saat ini kita kenal dengan istilah "gotong royong" atau Ekasila.

Melihat inti sari dari Pancasila yang di sebut dengan gotong royong, dapat kita lihat bahwa, dalam mendirikan suatu wilayah tidak mungkin hanya ada satu individu saja yang mampu mendirikan suatu daerah, tentu individu tersebut membutuhkan individu lainnya, sehingga terbentuklah suatu kelompok masyarakat. Dari kelopok masyarakat kemdian terbentuk suatu golongan masyarakat baru dengan kepercayaan-kepercayaan tertentu. Negara kita terbentuk dari adanya kerjasama dari berbagai aliran dan golongan-golongan, tidak memandang minoritas dan mayoritas tertentu. Jika negara kita di dirikan atas pandangan golongan minoritas atau minoritas, mungkin saat ini negara kita ini tidak di sebut negara kesatuan republic Indonesia (NKRI) melainkan negara agama yang di dalamnya hanya di huni oleh satu golongan agama tertentu atau ras tertentu, entah itu negara Islam, negara Kristen ataupun negara aliran kepercayaan lainnya.

Apakah kebangsaan itu? Soekarno mengutip definisi Ernest Renan mengenai gagasan le desir deter ensemble, (atau kehendak untuk bersatu) sebagai syarat untuk disebut sebagai suatu bangsa:

“...bangsa Indonesia, Natic indinesia, bukanlah sekedar satu golongan orang yang hidup dengan le desir deter ensemble, di atas daerah yang kecil seperti Minangkabau, atau Madura, atau Sintang, tetapi bangsa Indonesia ialah seluruh manusia-manusia yang menurut geo-politik yang telah ditentukan oleh Allah S.W.T., tinggal dalam kesatuan semua pulau-pulau Indonesia dari unjung utara Sumatra sampai ke Irian! Seluruhnya menjadi satu, sekali lagi... saya yakin tidak ada satu golongan diantara 
tuan-tuan yang tak mufakat, baik islam maupun golongan yang dinamakan golongan kebangsaan. Kesitulah kita harus menuju semuanya" (Setneg:71-72)

Hubungan agama dan etika politik selanjutnya juga disebut ketika Soekarno menjabarkan dasar ketuhanan:

"Prinsip ketuhanan! Bukan saja bangsa Indonesia ber-Tuhan, tetapi masing-masing orang Indonesia hendaknya ber-Tuhan, Tuhannya sendiri. Yang Kristen menyembah Tuhan menurut petunjuk Isa Almasih, yang Islam menurut petunjuk Nabi Muhammad S.A.W., orang Budha menjalankan ibadatnya menurut kitab-kitab yang ada padanya. Tetapi marilah kita semuanya ber-Tuhan. Hendaknya negara Indonesia ialah negara yang tiap-tiap orangnya dapat menyembah Tuhannya dengan cara yang leluasa. Segenap rakyat hendaknya ber-Tuhan secara kebudayaan, yakni dengan tiada egoisme agama." (Setneg:77)

Negara bangsa ini sejak pertama kali berdiri sudah dihadapkan dan didasarkandengan fakta kemajemukan di sana-sini, sehingga itu pula yang membuat para founding father melepaskan jubah-jubah perbedaan mereka. Mereka menyatukan serta merumuskan visi untuk membangun negara ini. Ancaman mendasar terhadap negara demokratis yang multicultural ini adalah munculnya budaya sectarian. Salah satu perwujudan sectarian adalah sikap antitoleran terhadap "yang lain".

Keprihatinan akan penghayatan gotong royong dewasa ini salah satunya yaitu gerakan intoleran atau antitoleran terhadap yang lain. Hal ini dapat kita lihat dari kasus yang menimpa jemaat kristiani ditiga gereja yang ada di kota jambi, dimana masyarakat yang menjadi mayoritas lebih berkuasa atas daerah tersebut sedangkan masyarakat minoritas tidak dapat menerima hak mereka. Selain itu pemerintah hanya bisa menuruti kemauan golongan mayoritas saja. Sedangkan jika kita melihat dari teori terbentuknya negara Indonesia dapat dipastikan bahwa negara kita ini terbentuk dari adanya gotong royong dari berbagai golongan tanpa memandang manyoritas dan minoritas. Karena negara yang baik adalah negara yang menjunjung ting persatuan dan kesatuan bangsa.

Munculnya peraturan daerah (Perda) yang mengacu pada Syariat Islam di beberapa daerah seperti di Tangerang, Indramayu, dan Jember, segera menimbulakn persoalan bagi negara-bangsa multikultur dan demokratis seperti Indonesia. Tidak hanya karena perda itu telah melanggar hierarki konstitusi, melainkan juga karena Perda itu sangat superfisial dan tidak substansial, seperti aturan memakai baju koko setiap hari jumat bagi pria, perempuan wajib berjilbab, dan menunda pekerjaan saat adzan tiba, larangan perempuan keluar malam, dan sebagainya. Sesungguhnya kasus itu tak perlu terjadi jika pemerintah daerah memiliki komitmen pada aturan main, bahwa 
negara-bangsa ini adalah negara hokum (rechtstaat) dan kebangsaan Indonesia adalah kebangsaan yang multicultural.

Negara harus berangkat dari kepentingan seluruh elemen warga negara yang multikulturan ini, di mana dalam hal itu mereka diwakili parlemen dan dieksekusi pemerintah. Adanya perda itu menandakan telah munculnya paham sectarian (golongan) dalam suatu komunitas pemerintah daerah yang kemudian mengintervensi pembuatan aturan kemasyarakatan yang bersifat public itu. Jika kekuatan sectarian itu dibiarkan berlarut-larut, maka bukan hanya saja mengancam namun juga dapat membinasakan karakter negara-bangsa Indonesia yang multicultural, secara lebih jauh mungkin Indonesia akan mengalami suatu kolaps social-kebangsaan.

Melihat teori kepentingan seluruh elemen warga negara yang multicultural. Apakah kota jambi yang sedang menciptakan suatu kasus baru-baru ini dapat dikatakan memperhatikan kepentingan seluruh elemen wargannya? Jika dilihat dari kasusnya, maka sebagian golongan akan berpandangan bahwa daerah tersebut telah menganut paham sectarian dimana golongan tertentu yang menjadi mayoritas daerah bisa menjadi pengatur pembuatan aturan bagi masyarakat, sehingga bisa terjadilah kasus-kasus semacam itu.

Soekarno menggagas negara multicultural khas Indonesia dengan mengetengahkan konsep gotong royong. Konsep gotong royonglah yang memungkinkan semua unsur yang berbhinneka di tanah air Indonesia diakui keberadaannya. Konsep gotong royong yang membuat pluralisme mekar dengan subur. Lebih lanjut, konsep gotong royonglah yang membuat semua elemen yang ada bisa merasa sederajat dan menyumbang sesuatu bagi Indonesia. Jadi, tidak salah jika konsep gotong royong menjadi dasar bagi bangunan Indonesia yang multikultur. Mengapa? Karena, terminus gotong royong itu sendiri pun merupakan sebuah cetusan pengedepanan semangat multicultural yang menghargai setiap perbedaan demi kemajuan Bersama.

Indonesia didirikan untuk semua warga Indonesia. Dengan kata lain, jangan lagi mengedepankan agama jika sudah berbicara mengenai ke-indonesia-an. Semangat gotong royong bangsa ini sudah terpatri dalam sanubari manusia Indonesia sejak semula. Hebatnya hal tersebut dilalui dengan musyawarah-mufakat dalam mencapai persetujuan bagi kebaikan bangsa yang majemuk secara keseluruhan.

Setelah melihat teori-teori yang ada dan saya coba kaitkan dengan kasus yang saya analisis maka saya dapat menyimpulkan bahwa: 
Kota Jambi saat ini masih dalam pengaruh kehidupan masyarakat golongan per golongan, yang jika kita lihat pada kasus dimana golongan yang menjadi mayoritas akan lebih berpengarus di pemerintahan dibandingkan dengan golongan minoritas.

Masyarat di kota tersebut, masih kurang bisa memaknai arti dari dasar negara Indonesia, yang jika kita lihat kembali sila kedua sampai dengan kelima dalam Pancasila yang berbunyi. Sila kedua, Kemanusiaan yang adil dan beradab, bagaimana cara masyarakat tersebut memaknai tentang isi dari sila kedua ini? Bagaimana cara mereka bisa bersikap adil dengan sesame masyarakat lainnya tanpa memandang minoritas ataupun mayoritas. Sila ketiga, Persatuan Indonesia, Bagaimana cara masyarakat kota itu memaknai tentang persatuan suatu negara? Jika dilihat dari kasus yang terjadi saya merasa bahwa di kota tersebut masih mengalami perpecahan antar golongan dan untuk meciptakan suatu persatuan masih cukup sulit karena masyaakat di kota tersebut masih berpikir menggunakan sistim mayoritas yang lebih berkuasa. Sila keempat, kerakyatan yang dipimpin oleh hikmat, kebijaksanaan, dalam permusyawaratan perwakilan, pada sila kali ini pemerintahan harus lebih berperan besar dalam menanganis kasus-kasus perpecahan antar golongan seperti ini. Bagaimana cara pemerintahan setempat memaknai tentang kepemimpinan yang adil bagi rakyatnya, sehingga masih sering terjadi masalah perpecahan antar golongan dan kekuasaan ditangan mayoritas. Sila kelima, keadilan social bagi seluruh rakyat Indonesia, melihat kontek masalah yang sedang terjadi di kota jambi, saya melihat bahwa masyarakat minoritas di kota tersebut masih belum mendapatkan keadilan dari pemerintahan dan dari masyarakat yang menjadi mayoritas di kota itu.

Pemerintahan yang bersikap kurang adil bagi masyarakatnya sendiri dapat dikatakan sebagai pemerintahan yang sangat gagal, mengapa? Karena, pemerintahan tersebut masih kurang mampu menciptakan suasana damai antar masyarakat, sehingga terbentuklan perpecahan masyarakat menjadi golongan masyarakat menurut kepercayaan masing-masing. Jika seperti itu, bagaimana mungkin masyarakat dengan kepercayaan ternentu bisa mendapatkan keadilan dari lingkungannya jika golongan tersebut tidak memiliki anggota yang dapat mengalahkan mayoritas di kota tersebut.

Saat ini sering terjadi persaingan antar golongan islam, kristiani, ataupun golongan kepercayaan. Soekarno pernah berkata dalam pidatonya saat siding dalam pembahasan pembentukan dasar negara Indonesia, kata-kata tersebut berbunyi sebagai berikut: 
"baik saudar-saudara yang bernama kaum kebangsaan yang di sini, maupun saudarasaudara yang dinamakan kaum islam, semuanya telah mufakat ... kita hendak mendirikan suatu negara semua buat semua..." (Sekretariat Negara Republik Indonesia, hlm. 71)

"saya yakin tidak ada satu golongan diantara Tuan-tuan yang tidak mufakat, baik islam maupun golongan yang dinamakan golongan kebangsaan. Ke sinilah kita harus menuju semuanya.” (Sekretariat Negara Republik Indonesia, hlm. 74)

"untuk pihak islam, inilah tempat yang baik untuk memelihara agama...." (Sekretariat Negara Republik Indonesia, hlm. 75)

“oleh karena itu saya minta kepada saudara-saudara sekalian, baik yang bukan islam, maupun terutama yang islam, setujulah prinsip yang ketiga ini, yakni permusyawaratan perwakilan.” (Sekretariat Negara Republik Indonesia, hlm. 78)

"Marilah kita amalkan ... baik islam maupun kristen dengan cara yang berkeadaban ... maka prinsip yang kelima adalah Ketuhanan yang berkebudayaan ..." (Sekretariat Negara Republik Indonesia, hlm. 80-81) 


\section{Daftar Pustaka}

A. Sumber Utama

Dewantara, w agustinus, (2017), Diskursus Filsafat Pancasila, Yogyakarta: PT. Kanisius

Sekretariat Negara Republik Indonesia (1995), Risalah Sidang Badan Penyelidikan Usaha-Usaha Persiapan Kemerdekaan Indonesia (BPUPKI), Jakarta.

B. Sumber Pendukung

Sumber: https://www.bbc.com/indonesia/indonesia-45675216

Dewantara, A. (2017). Diskursus Filsafat Pancasila Dewasa Ini.

Dewantara, A. (2017). Filsafat Moral (Pergumulan Etis Keseharian Hidup Manusia).

DEWANTARA, A. W. (2016). GOTONG-ROYONG MENURUT SOEKARNO DALAM PERSPEKTIF AKSIOLOGI MAX SCHELER, DAN SUMBANGANNYA BAGI NASIONALISME INDONESIA (Doctoral dissertation, Universitas Gadjah Mada).

Dewantara, A. W. (2015). Pancasila Sebagai Pondasi Pendidikan Agama Di Indonesia. CIVIS, 5(1/Januari).

Dewantara, A. W. (2013). Merefleksikan Hubungan antara Etika Aristotelian dan Bisnis dengan Studi Kasus Lumpur Lapindo. Arete, 2(1), 23-40.

Dewantara, A. (2018). Alangkah Hebatnya Negara Gotong Royong (indonesia Dalam Kacamata Soekarno).

Dewantara, A. (2018). Pancasila Dan Multikulturalisme Indonesia. 